\title{
Consumption attributes and preferences on medicinal and aromatic plants: a consumer segmentation analysis
}

\section{Osman Inanç Güney ${ }^{1^{*}}$ iD}

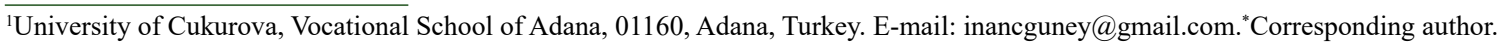

\begin{abstract}
In recent years, increasing interest in natural and traditional plants, which are an integral part of rural life, has been observed because of health concerns and new social trends. In this regard, medicinal and aromatic plants (MAPs) are becoming more popular among consumers. The purpose of this research is to investigate consumers' attitudes and behaviors toward MAPs in order to identify possible distinct consumer group and examine its potential linkage to the characteristics of the consumers'demographic and socio-economic status. To detect the perceived differences among consumers, the principal component and k-means cluster analysis were performed using the data from a face-to-face survey $(n=420)$ conducted in five major cities in the Mediterranean region of Turkey. The analysis allows segmenting the market into three homogenous clusters that have distinctive behavioral, attitudinal, and socio-demographic profiles. This segmentation is particularly effective for the dynamics and further expansion of the MAP sector as an important source for rural life.

Key words: consumer segmentation, cluster analysis, medicinal and aromatic plants, consumer behavior, rural development.
\end{abstract}

Atributos do consumo e percepções sobre plantas medicianis e aromáticas: uma análise da segmentação do consumidor

RESUMO: Nos últimos anos, o interesse crescente em plantas naturais e tradicionais, que são parte integrante da vida rural, tem sido observado devido a preocupações com a saúde e novas tendências sociais. A este respeito, plantas medicinais e aromáticas (PMA) estão se tornando mais populares entre os consumidores. O objetivo desta pesquisa é investigar as atitudes e comportamentos dos consumidores em relação às PMA, a fim de identificar possiveis grupos de consumidores distintos e examinar sua potencial ligação com as características do status demográfico e socioeconômico dos consumidores. Para detectar as diferenças percebidas entre os consumidores, a análise de componentes principais e a análise de cluster $k$-means foram realizadas usando os dados de uma pesquisa face a face ( $n=420$ ) realizada em cinco grandes cidades da região mediterrânea da Turquia. A análise permite segmentar o mercado em três clusters homogêneos que possuem perfis comportamentais, atitudinais e sociodemográficos distintos. Esta segmentação é particularmente eficaz para a dinâmica e expansão do setor PMA como uma fonte importante para a vida rural.

Palavras-chave: segmentação de consumidores, análise de cluster, plantas medicinais e aromáticas, comportamento do consumidor, desenvolvimento rural.

\section{INTRODUCTION}

The natural environment had been a source of medicinal agents and food for thousands of years and played a crucial role on the evolution of Homo sapiens (VERHEYE,2010; CHANDRA et al., 2018). In recent years, the consumption of available natural resources has become a new challenge and a common approach worldwide (MATEESCU et al., 2014). Accordingly, several concepts such as green consumerism, which is a purchasing choice that expresses a preference for less environmentally harmful goods and services, have affected consumers' behavior. Moreover, the emerging trend of return to nature caused a preference shift from synthetic to herbal, natural, and traditional (ADAMS, 1990; GUNJAN et al., 2015).

The concerns on environmental conservation and consumption trend caused a shift toward the use of organic and ecological products for a healthy lifestyle; hence, interest on medicinal and aromatic plants (MAPs) consumption is emerging. Consequently, the development of trade opportunities for MAPs contributes to rural development by creating employment opportunities and increasing income (KULAK, 2018; MARSHALL, 2011; ROOSTA et al., 2017). In recent years, MAP commerce has started to become a promising sector and a source of economic growth with the increased utilization of food supplements for personal care and therapeutic 
usage (ROOSTA et al., 2017). These plants are presented in different forums and contents, reflecting a wide variety of markets, ranging from bulk to niche, to informal and seasonal, and to formal and regulated (MARSHALL, 2011).

MAPs contain biologically active chemical substances such as tannin, saponins, essential oils, flavonoids, alkaloids, and other chemical compounds and are essentially beneficial in terms of nutrition, cosmetics, flavor, therapy, and health care (MARSHALL, 2011; OKIGBO et al., 2009). The demand for plant-based medicines, health and pharmaceutical products, food supplements, cosmetics, and so on is increasing in both developed and developing countries (GUNJAN et al., 2015). Globally, $50 \%$ of MAPs are used in food, $25 \%$ in cosmetics, and $25 \%$ in medicine industry (FAYDALIOĞLU \& SURUCUOGLU, 2011).

\section{Market structure}

MAPs are vital natural resources for sustaining the individual MAP businesses and the global industry. Global trade, commercialization, and the value of MAP resources are rapidly emerging as the largest herbal industry in the world (CHANDRA et al., 2018; CHANDRA \& SHARMA, 2018; ROOSTA et al., 2017). About three-quarters of the world's population use one or other form of these MAPs, and the global trade of MAP resources is growing at an annual rate of $11 \%$ from 2008 to 2013 (YADAN \& MISRA, 2012; ITC, 2016). This potential can create opportunities for the economy, sustainable livelihood, and employment for rural communities in the biodiversity-rich regions of the world (CHANDRA et al., 2018).

In Europe, at least 2,000 medicinal and aromatic herbs (1,200 of them are native) are used for different forms of consumption. Albania, Bulgaria, Poland, Hungary, and Turkey are the essential source countries for these plants. MAPs are reported extensively in the rural area with different environmental conditions in the Mediterranean where many MAPs originated from, either as wild or cultivated plants (e.g., rosemary, oregano, sage, thymus, peppermint, and garlic) (SOLOMOU et al., 2016). The cultivation facilities for MAPs are increasing, especially in the Mediterranean countries, and the majority are obtained from the natural environment $(80 \%)$, which shows the effect of these plants on rural development (AKBULUT \& BAYRAMOGLU, 2013; ROOSTAet al., 2017). Collection of wild plants is generally practiced at the rural areas of countries with relatively low-income level or countries hosting large disadvantaged social groups such as Nepal, Mexico, Turkey, Albania, and Bulgaria (CRAKER \& SIMON, 2004).

\section{Turkish market}

Considering the geographic, climatic, and topographic characteristics, Turkey is a rich country with diverse flora and endemic plants including a large variety of MAPs (AKBULUT \& BAYRAMOGLU, 2013; KORKMAZ et al., 2011). Although, Turkish consumers possess the traditional consumption attitude toward MAPs, the popularity of utilizing these plants is still growing. Aside from the health objectives, they utilized MAPs as spices and incenses and for spiritual feelings, pleasure, and industrial usage such as cosmetics and toiletries (ARTUKOĞLU et al., 2002).

The objective of this research was to determine and analyze the consumer preferences and attributes for MAPs and identify possible distinct consumer groups. In this context, this study particularly aimed to analyzing the possible relationship between consumer characteristics and marketing aspects of these products.

In order to develop a better understanding of consumers' motives and facilitate the design of marketing plans, the market segmentation process, which is an efficient and commonly used tool was used (BAKER \& BURNHAM, 2001). The results of this study will help to understand the consumption motivations for MAPs and in determining the consumption behavior of each motivation group through clustering. In this way, a more valuable marketing process could be designed for consumers to support the provision of a sustainable supply mechanism for these ecologically sensitive products. Moreover, identifying the expectations of the market from this product group is possible; hence, the proper product can be developed to meet the market demand. Furthermore, identifying the consumer's consumption density for MAPs may allow the development of a sustainable production structure for these products and prevent potential ecological threats.

\section{Literature background}

In recent years, scientific studies concerning MAPs have been increasing; however, consumer-related studies on this promising sector are still limited (JOKAR et al., 2017). ROOSTA et al.'s (2017) study on export target markets of MAPs aimed to prioritize the MAP importing countries using relative import advantage index and five other indices during the period of 2000-2014. According 
to them, Singapore, Japan, Germany, Malaysia, and USA are determined as the markets with highest importing advantage, and no firm has a dominant role in the MAP global market, which mostly followed the competitive structure. Among the 28 importing countries, China and USA have the largest import share and high potential in leading the MAP global import market. Meanwhile, LUBBE \& VERPOORTE (2015) reviewed an article on the utilization and trends of industrial plants. They categorized these plants according to their usage in the industry and identified their sources. They also emphasized the trade organization, price, and market trends, especially focusing on MAPs. The authors finally adverted about the industry expectations for MAPs in terms of quality practices and emphasized that many plant species are threatened because of overharvesting for medicinal or other use. BHATTACHARYYA et al. (2009) argued about the certification for conservation and management of wild MAP resources because they are an integral part of biodiversity and play a significant role in socio-economic development of rural communities. The majority of medicinal plants come from wild resources, which are ultimately prone to uncontrolled harvesting. Therefore, appropriate MAP conservation and management planning should be carried out by the government. MAP certification is an approach that attempts to involve all stakeholders of the MAP sector to improve the resource conservation and management practices. Furthermore, VAN DE KOP et al. (2006) argued in their book entitled Agro-food Chains and Networks for Development that continuous collection and increasing market demand of numerous plant species caused them to be threatened with extinction, which has a particularly negative impact on the income of the poorest sections of the rural areas. For rational and regulated collection, strong local communities or strict government control measures are necessary. High risks, transaction costs, and lack of trust among chain actors prevent smallholder producers from taking up cultivation of MAPs. Public-private collaboration is suggested as a way of reducing these constraints and securing market access to small producers. Meanwhile, LAMRANI-ALAOUI \& HASSIKOU (2018) identified and assessed the wild species that are affected by overharvesting, especially those in forest lands, and then identified the priority ones in Morocco. The results of their study revealed that increasing demand for MAP at the local, national, and international levels induced overharvesting and an increase in sale prices. This situation has brought some species, such as Laurus, Thymus, Lavandula, and Calendula, to a critical status in terms of their populations and associated ecosystems. In order to maintain a dynamic equilibrium between the demand and the offer of wild MAP species, a set of criteria and considerations following the principles of precaution, protection, and regulation are referred to in the study. CHANDRA et al. (2018) conducted research on branding strategies for Indian MAPs within the sustainable marketing orientation practices. They focused on differentiation, competitiveness, and authenticity strategies for MAPs as natural products traded across the globe. They argued that a clear linkage exists between Indian MAP resources and Indian religion, culture, tradition, scriptures, and lifestyle. There is an apparent scope of branding the herb resources with the perspective of the country of origin. This branding perspective for MAP resources will allow the authorities and policymakers to file and secure geographical indications for various valuable herb resources. Market demand also has to be satisfied from nurseries or alternative products, and specific control over wild populations and trade pathways has to be realized. In JOKAR et al. (2017) study on consumer acceptance of medical herbs, they reported that most consumers believe that medicinal plants can improve their health and eating quality and protect them from diseases. Consumers prefer MAPs because of their fewer side effects and affordable prices. Therefore, consumers are expected to be convinced in using medicinal herbs if detailed information about health benefits was provided. They also reported a positive relationship between the acceptance of MAPs and the education levels of the consumers. Similarly, MATEESCU et al. (2014) highlighted that individuals are consuming MAPs mainly for treating and preventing diseases. According to RASHIDI et al. (2012), the awareness and consumption level of MAPs among women are higher than men $(\mathrm{P}<0.001)$. Moreover, a significant difference exists between age groups because of the awareness and consumption levels $(\mathrm{P}<0.001)$; thus, the elderly individuals are more likely to consume MAPs. GUNJAN et al. (2015) stated in their research on marketing trends and future prospects of herbal plants that MAPs are non-toxic; hence, they have few side effects and are easily available at affordable prices, resulting in an increase in consumption of these plants in both the developing and developed countries. RAO et al. (2004) stated that consumers from Asian and African countries use MAPs because they are more effective than modern medicines, they do not have side effects, and they are cheaper. AKBULUT \& OZKAN (2016) argued in their study on MAP customer profiles that the most 
frequently preferred MAPs by Turkish consumers are mint, thyme, and linden. The consumers also stated that they buy MAPs for food (48.5\%) and treatment of system disorders, such as respiratory $(17.2 \%)$, digestive $(11.1 \%)$, cardiovascular $(5.1 \%)$, dermatological (5.1\%) and nervous (4\%), and other health problems (9\%). KORKMAZ et al. (2011) conducted a study on consumer preferences for MAPs in the Western Mediterranean region of Turkey. They reported that the factors influencing the initiation of MAP consumption are experiences from the past, medical advice, the Internet, television programs, magazines, books, and other written materials.

\section{MATERIALS AND METHODS}

\section{Data collection}

The data used in this research are based on the face-to-face consumer survey that was conducted in five provinces (Antalya, Adana, Mersin, Hatay, and Osmaniye) of the Mediterranean region of Turkey in the period May-August 2017. The interview procedure started with a brief introduction on the concept of MAPs to ensure that the term is totally understood by the respondents. In the research area, several individuals at the supermarkets and shopping malls were invited to participate the survey, and a structured questionnaire was given to the 420 participants; 400 valid responses were evaluated in the analysis. Table 1 shows the socio-demographic characteristics of the consumers involved in the present study.

\section{Survey design}

The questionnaire consisted of three sections, and the answers to the questions were designed according to the Likert-type scale (VECCHIO \& ANNUNZIATA, 2013). The first section focused on consumers' knowledge level and perceptions on MAPs. The second section contained questions on consumers' behaviors, attitudes, and preferences on MAPs. The last section is the general information of the survey participant's main sociodemographic and lifestyle characteristics.

Consumer groups with common attributes have different demands that may justify the development of different marketing activities. Thus, it is important to focus on consumer groups with common attributes and identify these groups to develop marketing programs for each segment. Clearly, a better classification of relevant buyer characteristics is needed (PUNJ \& STEWART, 1983).

\section{Data analysis}

An exploratory factor analysis was established to identify the set of factors and verify the structure within the set of the observed variables. This analysis was also conducted to reduce the number of items and to capture the central dimensions based on consumers'knowledge level and perceptions (FRANZ et al., 2012; HEISE \& THEUVSEN, 2017; VECCHIO \& ANNUNZIATA, 2013). The reliability of the related factors was tested using Cronbach's alpha as the measure of internal reliability consistency. Then, principal component

Table 1 - Socio-demographic characteristics of the sample ( $\%$ of respondents, $n=400$ ).

\begin{tabular}{|c|c|c|c|c|c|}
\hline Gender & $\%$ & Age (years) & $\%$ & Education & $\%$ \\
\hline Female & 52.3 & $\leq 35$ & 36.3 & Literate & 3.8 \\
\hline \multirow[t]{2}{*}{ Male } & 47.8 & $35-49$ & 37.3 & Primary school & 44.0 \\
\hline & & $\geq 50$ & 26.5 & High school & 32.8 \\
\hline Occupation & $\%$ & & & University or higher & 19.5 \\
\hline Officer & 7.8 & $\begin{array}{c}\text { Income } \\
\text { (TL) }\end{array}$ & $\%$ & & \\
\hline Employee & 32.8 & $\leq 1500$ & 34.5 & Household size & $\%$ \\
\hline Housewife & 30.0 & $1501-2500$ & 48.3 & $1-2$ & 16.5 \\
\hline Artisan & 12.0 & $3501-4500$ & 2.3 & $3-4$ & 52.6 \\
\hline Self-employed & 2.5 & $>4500$ & 2.5 & $\geq 5$ & 31.0 \\
\hline Unemployed & 5.0 & & & & \\
\hline Student & 9.3 & & & & \\
\hline Retired & 0.3 & & & & \\
\hline
\end{tabular}

TL: Turkish Lira. 
analysis (PCA) with varimax rotation was used to simplify and summarize the variables that load highly on one factor (CALLIERIS et al.2016; KRAUS, 2015). Variables with factor loadings of $\geq 0.4$ were removed from the factor set (BACKHAUS et al., 2011). Subsequently, the quality of the factor analysis was verified using the Kaiser-Meyer-Olkin criterion and the Bartlett test for sphericity with subsequent reliability analysis (HEISE \& THEUVSEN, 2017).

To identify possible distinct groups among consumers, the data was analyzed through cluster analysis, which has been a popular multivariate method in strategic management research when the objective is to identify groups of consumers with similar characteristics (FORSMAN, 2004). Objects in a specific cluster share many similar characteristics but are very different from objects not belonging to that cluster (SARSTEDT \& MOOI, 2014).

Onthis direction, firsthierarchicalclustering method with inspection of the agglomeration schedule and dendrogram was performed, which allowed us to decide the optimal number of clusters using Ward's method and Euclidean distance (KORNELIS et al., 2007; FORLEO et al., 2017). Then, k-means clustering method using the main factors from the PCA results was performed to obtain segments (FRANZ et al., 2012; HEISE \& THEUVSEN., 2017). To characterize the different groups in greater depth, the analysis of variance with post hoc tests was used (HEISE \& THEUVSEN, 2017).

Finally, to profile and describe the clusters, the mean comparisons using (bivariate) variance analysis one-way ANOVA and cross-tabulation with chi-squared statistics was calculated. To perform these variance analyses, the individual variables on socio-demographic and lifestyle characteristics and the variables describing consumption behaviors and attitudes on MAPs was used (FORLEO et al. 2017; FRANZ et al., 2012; HEISE \& THEUVSEN, 2017; VANHONACKER et al., 2007). All data were analyzed using SPSS Statistics 22 (IBM, Armonk, New York, USA).

\section{RESULTS AND DISCUSSION}

First, the factor analysis was performed to reduce the number of variables into fewer factors and determine the core dimensions of consumer involvement in the MAPs (VERBEKE \&VACKIER, 2004; FRANZ et al., 2012). In this context, The PCA method was used on the variables related to knowledge level and perceptions on MAPs, and four factors with 12 variables were obtained, which explains the $51.74 \%$ variance in the original data (Table 2). The PCA result showed that consumers' knowledge level and perceptions on MAPs can

Table 2 - Results of the factor analysis $(n=400)$

\begin{tabular}{|c|c|c|}
\hline Factors and related variables & Factor loading & Agreement $(\%)$ \\
\hline \multicolumn{3}{|c|}{ 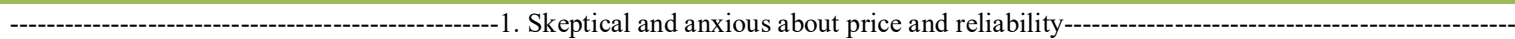 } \\
\hline I have no trust in the synthetic medicine sector & 0.765 & 54.7 \\
\hline I find the price of MAPs high & 0.646 & 51.0 \\
\hline I do not find the MAPs in the market to be reliable & 0.564 & 35.8 \\
\hline I do not have enough knowledge about MAPs & 0.469 & 38.6 \\
\hline \multicolumn{3}{|c|}{ 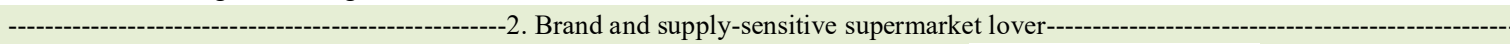 } \\
\hline I have problems accessing MAPs & 0.656 & 23.1 \\
\hline I take care to be branded while buying MAPs & 0.491 & 50.3 \\
\hline I have problems in supplying MAPs from supermarkets & 0.452 & 39.8 \\
\hline \multicolumn{3}{|c|}{ - Sensitive to health and the environment--1 } \\
\hline MAPs must be packaged & 0.716 & 71.6 \\
\hline I think that there is a lack of inspection on sales of MAPs & 0.642 & 54.1 \\
\hline Concerned about the depletion of MAPs in nature & 0.496 & 74.0 \\
\hline \multicolumn{3}{|c|}{ 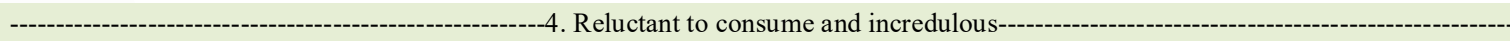 } \\
\hline I think there are side effects of medicinal and aromatic plants & 0.886 & 62.5 \\
\hline I do not think that MAPs are beneficial to health & 0.439 & 20.5 \\
\hline
\end{tabular}

Kaiser-Meyer-Olkin measure $=0.70$; explained variance $=51.74 \%$. Scale from $5=$ totally agree to $1=$ totally disagree. Agreement refers to the sum of the percent data relating to categories 4 and 5 . 
be reduced to the following four factors. Factor 1 expresses the tendency for MAP consumption, but information is lacking for these plants; hence, consumers are concerned about the reliability terms and price. Factor 2 reflects the problems in accessing the products in the market, especially the branded ones. Factor 3 represents the sensitivity on natural environment and food safety issues. Finally, Factor 4 is related to few benefits or possible side effects of these plants. The reliability test results demonstrate sufficient internal consistency (Cronbach's $\alpha=0.64$ ). Furthermore, variables related to MAP consumption are well suited for the factor analysis as the KaiserMeyer-Olkin measure of sampling adequacy is relatively high at 0.7 . Additionally, Bartlett's test of sphericity was statistically significant $(p=0.000)$, yielding correlation coefficients for the population with values other than zero.

Subsequently, hierarchical clustering was applied to the data set to determine the number of clusters, which was 3 . Then, k-means clustering was applied to define which cluster each observation belongs with the nearest mean. For each cluster obtained, the F-values for all clustering factors are smaller than 1, indicating that the clusters are highly homogeneous.

The factors obtained by PCA were correlated with the three clusters, which were previously identified by Wards method, using k-means clustering. Thus, it was able to identify which factor is more related to the obtained clusters. In order to examine the significant differences among the means of the clusters, Tuckey post hoc comparisons that complemented the cluster description was used (HEISE \& THEUVSEN, 2017). The results are shown in table 3.

As presented in table 3 , cluster 1 is composed of individuals who are reluctant to consume MAPs and who are concerned about the possible side effects of these products. The results revealed that the individuals belonging to the first cluster do not have sufficient information about these products. They also think that the prices of these products are significantly high because of lack of knowledge.

Cluster 2 consists of individuals who want to consume these plants, but problems with the supply occurred, especially in supermarkets. They also give importance to the branding of these products. Cluster 3 consists of consumers who are conscious of the natural environment and health care. They care about hygiene and safety conditions and accordingly prefer packaged products.

In order to define the clusters in more details, calculated cluster means of the factors for consumer preferences and attributes (place of purchase, consumption patterns and purposes, factors and reasons for consumption, and preferred products) and consumer characteristics. The highest average values were determined for the related factors of each cluster, which are presented in table 4.

As seen in table 4, Cluster 1 prefers to purchase MAPs mainly from herbalists, and their use of these plants is mainly influenced by media news and traditions. Moreover, these consumers utilized these plants in dried form and prepared them by brewing. Their purposes of consuming MAPs are for relaxation, flavor enrichment, and habit. Furthermore, they prefer the consumption of these plants because MAPs are natural and not synthetic. Finally, this cluster gives much attention on the smell of the products, and their most preferred products to purchase are linden, black cumin, mint, black pepper, thyme, cinnamon, garlic, and cumin.

Cluster 2 consists of consumers who purchased MAPs mainly from supermarkets, took the advice from doctors, friends, and herbalists, and were influenced by advertisements and traditions. They consume these plants for treatment, treatment

Table 3 - Result of the cluster analysis.

\begin{tabular}{|c|c|c|c|}
\hline \multirow[t]{2}{*}{ Factors } & \multicolumn{3}{|c|}{ 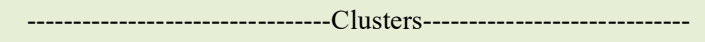 } \\
\hline & $1(n=143)$ & $2(\mathrm{n}=112)$ & $3(\mathrm{n}=145)$ \\
\hline Skeptic and anxious for price and reliability & $0.35006^{\mathrm{b}}$ & $-0.89081^{\mathrm{a}}$ & $0.34284^{\mathrm{b}}$ \\
\hline Brand and supply-sensitive supermarket lover & $-0.43501^{\mathrm{b}}$ & $0.71167^{\mathrm{a}}$ & $-0.12069^{\mathrm{c}}$ \\
\hline Concern to health and environment & $-0.25955^{\mathrm{b}}$ & $-0.51563^{\mathrm{b}}$ & $0.65424^{\mathrm{a}}$ \\
\hline Reluctant to consume and incredulous & $0.81176^{\mathrm{a}}$ & $-0.22961^{\mathrm{c}}$ & $-0.62321^{\mathrm{b}}$ \\
\hline
\end{tabular}

${ }^{* * *} \mathrm{P} \leq 0.001 ; \mathrm{a}, \mathrm{b}$, and $\mathrm{c}$ are Tamhane's $\mathrm{T} 2$ post hoc test. 
Table 4 - Summary of cluster attributes on MAPs.

\begin{tabular}{|c|c|c|c|}
\hline Attributes and preferences & Cluster 1 (n=143) & Cluster $2(\mathrm{n}=112)$ & Cluster 3 (n=145) \\
\hline Place of purchase & Herbalist & Supermarket & Herbalist \\
\hline $\begin{array}{l}\text { Factors affecting } \\
\text { consumption }\end{array}$ & News, customs and traditions & $\begin{array}{l}\text { Pieces of advice from friends, } \\
\text { herbalists, and doctors, } \\
\text { advertisement, news, customs } \\
\text { and traditions, }\end{array}$ & $\begin{array}{l}\text { Pieces of advice from doctors } \\
\text { and herbalists, news, customs } \\
\text { and traditions, religious beliefs }\end{array}$ \\
\hline Type of consumption & Brew, dried & Powdered & Brew, dried \\
\hline Purpose of consumption & $\begin{array}{l}\text { Relaxation, flavor enhancement, } \\
\text { habit }\end{array}$ & $\begin{array}{l}\text { Treatment, treatment support, } \\
\text { disease prevention, increase the } \\
\text { nutritional value }\end{array}$ & $\begin{array}{l}\text { Treatment, treatment support, } \\
\text { disease prevention }\end{array}$ \\
\hline Medical plant & Linden, black cumin & Linden, rosehip & Linden, black cumin \\
\hline Aromatic plant & $\begin{array}{l}\text { Mint, black pepper, thyme, } \\
\text { cinnamon, garlic, cumin }\end{array}$ & $\begin{array}{l}\text { Mint, black pepper, thyme, } \\
\text { garlic, cumin }\end{array}$ & $\begin{array}{l}\text { Mint, black pepper, thyme, } \\
\text { cinnamon, garlic, cumin }\end{array}$ \\
\hline Reasons for preference & $\begin{array}{l}\text { Naturalnessmore effective than } \\
\text { synthetic drugs }\end{array}$ & $\begin{array}{l}\text { Naturalness, low side effects, } \\
\text { environment friendly }\end{array}$ & Naturalness, low side effects \\
\hline Factors affecting purchase & Odor & $\begin{array}{l}\text { Odor, color, expiry date, price, } \\
\text { brand }\end{array}$ & Odor, color, expiration date \\
\hline Education & Low & High & Medium \\
\hline Income & Medium & High & Low \\
\hline Gender & Equal & Equal & Mostly women \\
\hline
\end{tabular}

MAPs: Medicinal and aromatic plants.

support, disease prevention, and increase the nutritional value. Their preference for consumption is due to the plants' natural characteristics, fewer side effects, and environmental-friendly attributes. Cluster 2 members preferred mostly linden, rosehip, mint, black pepper, thyme, garlic, cumin in powder, or milled product form. The factors affecting MAP purchasing behavior of this cluster are the odor, color, expiry date, price, and brand name. Cluster 3 consisted of consumers who purchase MAPs mainly from herbalists and in dried form. Unlike the other groups, religious beliefs affect the MAP consumption in this cluster. The general purposes for consumption of these plants are treatment and treatment support. Furthermore, they preferred these plants because they are natural and have fewer side effects than synthetic drugs. The most preferred MAPs for this cluster are linden, black cumin, mint, black pepper, thyme, cinnamon, garlic, and cumin. The purchasing behavior of Cluster 3 members is mainly influenced by odor, color, and expiration date.

The profile of each cluster was identified through the socio-demographic and lifestyle variables, and the results are presented in table 4 .

\section{CONCLUSION}

It is increasingly accepted all over the world that synthetic materials commonly used in food and pharmaceutical industries cause many diseases, which leads to an increased concern about the consumption of natural products (AKBULUT \& BAYRAMOGLU, 2013). In addition, social trends such as preserving traditions and consuming natural and organic products are becoming popular worldwide (KILCHLING et al., 2009). These developments led to an increase in global demand for the natural and organic forms of medicines and foods. MAPs that are widely used in pharmaceutical and food industries constitute a major source of natural and organic compounds, and they are essential in everyday life (BENJAMIN, 2016). These developments are also in the agenda of the EU that supports MAP sector for candidate countries with pre-accession assistance program for rural development as a key activity.

The demand for MAPs will increase in both developed and developing countries in the future, depending on population growth and awareness of the economic and health benefits of natural products. The demand is also dependent on the wide acceptance of MAPs as an alternative to synthetic medicines and food. A shift in global trend from synthetic to natural, which is known as "return to nature," has already been observed (RAO et al. 2004; GUNJAN et al., 2015). 
Results of the factor analysis showed four factors with high correlation. When the impact levels of the variables related to these factors are examined, it is understood that consumers have high sensitivity to hygiene and reliability issues. In addition, some consumers are cautious about the consumption of these products because of the lack of information and particular concern about the possible side effects of MAPs. Furthermore, consumers' concern about synthetic medicines and processed foods are the main source of interest on MAP consumption in recent years.

The three clusters obtained from the cluster analysis reveal consumers' unique attitude and behavior characteristics. Accordingly, Cluster 1 was reported to be composed of relatively older and less educated individuals who were skeptic of the consumption because of these plants' possible side effects. Low consumption tendency is also due to the fact that the cluster members find the MAP prices to be high. More awareness and information campaign could be useful to increase the consumption for this cluster. Moreover, unlike other clusters, Cluster 1 prefers MAPs mostly for non-therapeutic purposes.

Cluster 2 represents individuals who preferred organized retailers (supermarkets) in their purchasing activities and have problems accessing branded MAPs. Compared with other clusters, their income and education level are relatively high, and the advertising activities have a great effect on their purchasing behaviors. The MAP demand of this cluster is increased because of the enrichment of the nutritive value of food consumed. Moreover, the income level of this cluster is high; hence, the price affects the MAP purchase. To reach this consumer group, branding and the availability of these products in supermarkets should be increased.

The third cluster consisted of consumers who are cautious about processed foods and drugs and prefer natural products to adopt the theme of "return to nature"; thus, they are sensitive to environmental, food safety, and health issues in consumption. In this context, they mainly prefer these products as packaged. Unlike other clusters, religious beliefs are essential factors for consumption in Cluster 3.

In the present study, common factors affecting consumption and purchasing behavior of consumers have been identified. Accordingly, the odor affects the purchase of all groups. Moreover, the naturalness of these products is identified as the common choice for all consumers. Lastly, the common consumption form of these plants is usually brewed or powdered.

\section{DECLARATION OF CONFLICT INTERESTS}

OF

The authors declare no conflict of interest. The founding sponsors had no role in the design of the study; in the collection, analyses, or interpretation of data; in the writing of the manuscript, and in the decision to publish the results.

\section{REFERENCES}

ADAMS, R.. Green consumerism and the food Industry: early signs of big changes to Come. British Food Journal, v.92, n.9, p.11-14, 1990. Available from: <https:/www.emeraldinsight.com/ doi/pdfplus/10.1108/00070709010142685>. Accessed: Apr. 17, 2018. doi: $10.1108 / 00070709010142685$.

AKBULUT, S.; BAYRAMOGLU M.M. The trade and use of some medical and aromatic herbs in Turkey. Ethno Med, v.7, n.2, p.67-77. 2013. Available from: <http://www.krepublishers. com/02-Journals/S-EM/EM-07-0-000-13-Web/S-EM-07-2-00013-Abst-PDF/S-EM-07-2-067-13-252-Akbulut-S/S-EM-07-2067-13-252-Akbulut-S-Tt.pdf $>$. Accessed: Apr. 05, 2018. doi: 10.1080/09735070.2013.11886446.

AKBULUT, S.; ÖZKAN, Z.A. Herbalist-customer profile in medicinal and aromatic herbs trade: a case study of Kahramanmaraş, Turkey. Kastamonu Univ., Journal of Forestry Faculty, v.16, n.1, 246-252. 2016. Available from: <http:// dergipark.gov.tr/kastorman/article/260578>. Accessed: Jun. 15, 2018. doi: $10.17475 /$ kujff. 88816 .

ARTUKOĞLU, M. et al. An evaluation of medicinal and aromatic plant trade in the world, in the EU and in Turkey. Agro Food Industry Hi Tech, November/December (2002), p.19-22. 2002.

BACKHAUS, K., et al. Multivariate analysemethoden: eine anwenderorientierte einführung. Springer, Berlin. 2011. Available from: <https://www.springer.com/de/book/9783662460764>. Accessed: Jun. 15, 2018. doi: 10.1007/978-3-662-46076-4.

BAKER, G.A.; BURNHAM, T.A. Consumer response to genetically modified foods: market segment analysis and implications for producers and policy makers. Journal of Agricultural and Resource Economics, v.26, n.2, p.387-403. 2001. Available from: <http://www.jstor.org/stable/40987116>. Accessed: Apr. 18, 2018.

BENJAMIN, S. Examining the development, regulation, and consumption of functional foods. in: Nithya V. bioactive compound analysis of Coriandrum Sativum L. against microbial keratitis. IGI Global, 109-125. 2016. Available from: <https://www.igi-global. com/book/examining-development-regulation-consumptionfunctional/147340\#table-of-contents $>$. Accessed: Jul. 22, 2018. doi: 10.4018/978-1-5225-0607-2.

CALLIERIS, R., et al. Different consumer behaviours for organic food in Tunisia. a cluster analysis application. NewMedit, v.15, n.2, p.53-62. 2016. Available from: <https://newmeditiamb. it/2016/06/08/different-consumer-behaviours-for-organic-food-intunisia-a-cluster-analysis-application/>. Accessed: May, 07, 2018. 
CRAKER, L.E.; SIMON, J.E. The future for medicinal and aromatic plants, in: Lange D. Medicinal and aromatic plants: trade, production, and management of botanical resources. Acta Hortic, v.629, p.177-197. 2004. Available from: <https://www. actahort.org/books/629/629_25.htm>. Accessed: Jun. 18, 2018. doi: 10.17660/ActaHortic.2004.629.25.

FAYDALIOĞLU, E.; SURUCUOGLU, M.S. History of the use of medical and aromatic plants and their economic importance. Kastamonu Univ. Journal of Forestry Faculty, v.11, n.1, p.5267. 2011. Available from: <http://dergipark.gov.tr/kastorman/ issue/17236/180072>. Accessed: Apr. 05, 2018.

FRANZ, A., et al. Concerns about animal welfare: a cluster analysis of German pig farmers. British Food Journal, v.114, n. 10, p.14451462. 2012. Available from: <https://www.emeraldinsight.com/ doi/pdfplus/10.1108/00070701211263019>. Accessed: May, 21, 2018. doi: $10.1108 / 00070701211263019$.

FORLEO, M.B., et al. Food consumption and eating habits: a segmentation of university students from central-south Italy. New Medit, v.16, n.4, p.56-65. 2017. Available from: <https:// newmedit.iamb.it/2017/12/08/food-consumption-and-eatinghabits-a-segmentation-of-university-students-from-central-southitaly/>. Accessed: May, 07, 2018.

FORSMAN, S. How do small rural food-processing firms compete? a resource-based approach to competitive strategies. Agr Food Sci, v.13, n.1, p.1-13. 2004. Available from: <http://jukuri. luke.fi/handle/10024/441138 >. Accessed: Jun. 14, 2018. doi: 10.23986/afsci.5790.

GUNJAN, M., et al. Marketing trends \& future prospects of herbal medicine in the treatment of various disease. World Journal of Pharmaceutical Research, v.4, n.9, p.132-155. 2015. Available from: $<$ http://www.wjpr.net/dashboard/abstract id/3518>. Accessed: May. 21, 2018.

HEISE, H.; THEUVSEN L. What do consumers think about farm animal welfare in modern agriculture? attitudes and shopping behaviour. International Food and Agribusiness Management Review, v.20, n.3, p.379-399. 2017. Available from: $<$ https://www. wageningenacademic.com/doi/abs/10.22434/IFAMR2016.0115>. Accessed: Apr. 14, 2018. doi: 10.22434/IFAMR2016.0115.

JOKAR, N.K., et al. Consumers' acceptance of medicinal herbs: an application of the technology acceptance model (TAM). Journal of Ethnopharmacology, v.207, p.203-210 2017. Available from: <https://www.sciencedirect.com/science/ article/pii/S0378874117312977>. Accessed: Jun. 15, 2018. doi: 10.1016/j.jep.2017.06.017.

KILCHLING, P., et al. Demand for non-timber forest products: surveys of urban consumers and sellers in Switzerland. Forest Policy and Economics, v.11, n.4, p.294-300. 2009. Available from: $<$ https:// www.sciencedirect.com/science/article/pii/S1389934109000550>. Accessed: Jun. 15, 2018. doi: 10.1016/j.forpol.2009.05.003.

KORKMAZ, M., et al. Consumer preferences for medicinal and aromatic plant products: surveys of urban consumers and sellers in western Mediterranean region of Turkey. Journal of Medicinal Plants Research, v.5, n.10, p.2054-2063. 2011. Available from: $<$ https://academicjournals.org/journal/JMPR/article-abstract/ BF0DA6019821>. Accessed: May, 07, 2018. doi: 10.5897/JMPR.
KORNELIS, M., et al. Consumer selection of food-safety information sources. Risk Analysis, v.27, n.2, p.327-335. 2007. Available from: <https://onlinelibrary.wiley.com/doi/epdf/10.1 111/j.1539-6924.2007.00885.x>. Accessed: Jun. 21, 2018. doi: 10.1111/j.1539-6924.2007. 00885.x.

KRAUS, A. Factors influencing the decisions to buy and consume functional food. British Food Journal, v.117, n.6, p.1622-1636. 2015. Available from: <https://www.emeraldinsight.com/doi/ full/10.1108/BFJ-08-2014-0301>. Accessed: Jul. 08, 2018. doi: 10.1108/BFJ-08-2014-0301.

KULAK, M. Bibliometric analysis of studies in medicinal and aromatic plants for rural development, $\mathbf{1 7}^{\text {th }}$ International Scientific Conference Engineering for Rural Development, Jelvaga. 2018 Available from: <http://tf.llu.lv/conference/proceedings2018/>. Accessed: Apr. 14, 2018.

MARSHALL, E. Health and wealth from medicinal aromatic plants, rural infrastructure and agro-industries division food and agriculture organization of the United Nations. Diversification booklet, 17, Rome. 2011. Available from: <http://www.fao.org/3/ a-i2473e.pdf>. Accessed: Jun. 18, 2018.

MATEESCU, I., et al. Medicinal and aromatic plants-a statistical study on the role of phytotherapy in human health. Bulletin UASVM-CN Animal Science and Biotechnologies, v.71, n.1, p.14-19. 2014. Available from: <http://journals.usamvcluj.ro/ index.php/zootehnie/article/view/9731>. Accessed: Jun. 18, 2018. doi: 10.15835/buasvmcn-asb:71:1:9731.

OKIGBO, R.N., et al. Advances in selected medicinal and aromatic plants indigenous to Africa. Journal of Medicinal Plants Research, v.3, n.2, p.086-095. 2009. Available from: $<$ https://academicjournals.org/journal/JMPR/article-full-text-pdf/ F7CC0D314745 >. Accessed: May, 17, 2018. doi: 10.5897/JMPR.

ROOSTA, A.R.,et al. Export target markets of medicinal and aromatic plants. Journal of Applied Research on Medicinal and Aromatic Plants, v.7, p.84-88. 2017. Available from: <https:// www.sciencedirect.com/science/article/pii/S221478611630081X>. Accessed: Apr. 25, 2018. doi: 10.1016/j.jarmap.2017.06.003.

PUNJ, G.; STEWART, D.W. Cluster analysis in marketing research: review and suggestions for application. Journal of Marketing Research, v.20, n.2, p.134-148. 1983. Available from: <https:// journals.sagepub.com/doi/full/10.1177/002224378302000204>. Accessed: May, 16, 2018. doi: 10.1177/002224378302000204.

RASHIDI, S., et al. Evaluation of knowledge, belief and operation of Yasouj people towards pharmaceutical plants. J. Med. Plants, v.11, n.Suppl. 8, p.177-183. 2012. Available from: <http://jmp.ir/ article-1-489-en.pdf>. Accessed: Jun. 15, 2018.

RAO, M.R., et al. Medicinal and aromatic plants in agroforestry systems. Agroforestry Systems, v.61, p.107-122. 2004. Available from: <https://link.springer.com/article/10.1023/ B\%3AAGFO.0000028993.83007.4b>. Accessed: Jul. 14, 2018. doi: 10.1023/B: AGFO.0000028993.83007.4b.

SARSTEDT, M.; MOOI, E. A Concise guide to market research, Springer texts in business and economics. Springer, Berlin Heidelberg. 2014. Available from: <https://www.springer. com/gp/book/9783662519813>. Accessed: Apr. 07, 2018. doi: 10.1007/978-3-642-53965-7.

Ciência Rural, v.49, n.5, 2019. 
SOLOMOU, A.D., et al. Medicinal and aromatic plants diversity in Greece and their future prospects: a review. Agricultural Science, v.4, n.1, p.9-21. 2016. Available from: <http://www.todayscience. org/as>. Accessed: June. 18, 2018. doi: 10.12735/as.v4i1p09.

VANHONACKER, F., et al. Segmentation based on consumers' perceived importance and attitude toward farm animal welfare. International Journal of Sociology of Food and Agriculture, v.15, n.3, p.84-100. 2007. Available from: <http://www.ijsaf.org/ index.php/ijsaf/article/view/19>. Accessed: May, 07, 2018.

VECCHIO, R.; ANNUNZIATA, A. Consumers' attitudes towards sustainable food: a cluster analysis of Italian university students.
New Medit, v.12, n.2, p. 47-56. 2013. Available from: <https:// newmedit.iamb.it/share/img_new_medit_articoli/942_47 vecchio.pdf>. Accessed: May, 07, 2018.

VERBEKE, W.; VACKIER, I. Profile and effects of consumer involvement in fresh meat, Meat Science, v.67, p.159-168. 2004. Available from: <https://www.sciencedirect.com/science/ article/pii/S0309174003002717>. Accessed: Jun. 14, 2018. doi: 10.1016/j.meatsci.2003.09.017.

VERHEYE, W.H. Soils, plant growth and crop production. In: MÁTHÉ Á. Medicinal and aromatic plants, EOLSS Publishers/ UNESCO, Vol. II, UK:322-349. 2010. 